\title{
PELAKSANAAN BAURAN PEMASARAN MEETING INCENTIVE CONFERENCE EXHIBITION DI BALI NUSA DUA CONVENTION CENTER
}

\author{
Nelsye Lumanauw \\ Email: nelsye.lumanauw@pib.ac.id \\ POLITEKNIK INTERNASIONAL BALI
}

\begin{abstract}
Nowadays travel is not only for leisure time but it is also for business purposes, such as Meetings, Incentives, Conventions and Exhibitions (MICE) activity. The MICE activity is a form of tourism travel in which groups of people, usually plan well in advance for a particular purpose. The industry of MICE is growing rapidly and this results in an intensified competition among the event venues that are keen to attract more meetings and conventions. Challenges and trends of convention centers are faced by the Bali Nusa Dua Convention Centre (BNDCC). It is because of an increased number of venues and meeting space.

This research uses descriptive qualitative analysis. Data were collected through interviews, observation, and documentation of the product, price, place, promotion, process, people and physical evidence as $7 P$ marketing mix of BNDCC. The collected data were then analyzed and evaluated according to the $7 P$ marketing mix and select the improvements which can be done.

The conclusion of this research is the 7P marketing mix used in the events section of BNDCC is good. There is one element, people, as part of the marketing mix, which is limited. Improvements can be done by improving sales team performance. The team is important to communicate the product and meet the individual needs of the person experiencing it.
\end{abstract}

Keywords: MICE Industry, Marketing Mix, Event Venue, Convention Center

\begin{abstract}
Abstrak
Perjalanan saat ini tidak hanya untuk waktu luang tetapi menggabungkan dengan kegiatan bisnis, seperti pertemuan, insentif, konvensi dan pameran atau Meetings, Incentives, Conventions and Exhibitions (MICE). Kegiatan MICE adalah bentuk perjalanan wisata di mana sekelompok orang telah merencanakan dengan baik kegiatan tersebut untuk tujuan tertentu. Industri MICE berkembang pesat dan ini menghasilkan persaingan yang semakin intensif di antara tempat acara
\end{abstract}


yang ingin menarik lebih banyak pertemuan dan konvensi. Tantangan dan tren pusat konvensi dihadapi oleh Bali Nusa Dua Convention Center (BNDCC), karena peningkatan jumlah tempat dan ruang pertemuan.

Penelitian ini menggunakan analisis deskriptif kualitatif. Pengumpulan data dilakukan dengan wawancara, observasi dan dokumentasi yang dilakukan terhadap produk, harga, tempat, promosi, proses, orang, dan bukti fisik sebagai 7P bauran pemasaran BNDCC. Data yang terkumpul kemudian dianalisis dan dievaluasi sesuai dengan bauran pemasaran 7P dan memilih perbaikan yang dapat dilakukan.

Kesimpulan dari penelitian ini adalah bauran pemasaran $7 \mathrm{P}$ yang digunakan di bagian acara BNDCC baik. Ada satu elemen, orang, sebagai bagian dari bauran pemasaran, yang terbatas. Perbaikan dapat dilakukan dengan meningkatkan kinerja tim penjualan. Tim penting untuk mengkomunikasikan produk dan memenuhi kebutuhan individu dari orang yang mengalaminya.

Kata Kunci: Industri MICE, Bauran Pemasaran, Tempat Acara, Pusat Konvensi.

\section{Pendahuluan}

Dewasa ini, perjalanan wisata tidak hanya dimaksudkan untuk menikmati keindahan budaya, panorama alam dan kuliner, namun dikombinasikan dengan kegiatan pertemuan (Meeting), perjalanan insentif (Incentive), konferensi (Conference) dan pameran (Exhibition) atau disingkat MICE. Hal ini bisa dipahami mengingat terdapat berbagai macam organisasi, seperti politik, ekonomi, sosial dan budaya melakukan kegiatan MICE secara reguler, untuk membicarakan hal-hal terkait kemajuan organisasi dan anggotanya.

Maraknya berbagai organisasi melakukan kegiatan MICE dalam berbagai bentuk mendorong industri MICE di Indonesia mengalami kemajuan yang cukup pesat. Para pelaku bisnis melihat MICE sebagai suatu industri yang kompleks sehingga dapat dijadikan peluang bisnis yang sangat menjanjikan bagi banyak pihak yang terlibat sebagai penyelenggara dalam kegiatan industri ini (Linda Desma Yunita1 dan Tri Handayani, 2018). Peserta MICE selain dari anggota organisasi juga berasal dari 
masyarakat luas atau orang-orang tertentu yang diundang berdasarkan jenis acara yang dilaksanakan (Darmawan Damanik dan FX Setiyo Wibowo, 2018).

Pesatnya industri MICE harus didukung oleh keberadaan tempat kegiatan MICE itu sendiri. Kegiatan pada taraf regional maupun global menunjukkan adanya persaingan ketat pada destinasi MICE. Destinasi MICE dituntut untuk memiliki tempat penyelenggaraan kegiatan (venue) sebagai salah satu barometer. Berdasarkan hal tersebut, hal ini menjadi sebuah tantangan bagi industri MICE Indonesia untuk dapat menyediakan venue yang bisa bersaing baik regional maupun internasional serta mampu meningkatkan jumlah kunjungan, lama tinggal, dan pengeluaran belanja dari wisatawan mancanegara tujuan bisnis MICE (Peraturan Menteri RI, no 2 Tahun 2017).

Nusa Dua khususnya area Indonesia Tourism Development Centre (ITDC) merupakan salah satu destinasi MICE unggulan di Bali, dengan dimilikinya infrastruktur yang baik, seperti 4000 kamar hotel bintang 4 dan 5, lapangan golf, restoran, dan pantai pasir putih. Berbagai ajang peristiwa besar, baik nasional ataupun internasional, dilaksanakan di Nusa Dua. Bali Nusa Dua Convention Center (BNDCC) menjadi salah satu tempat diadakannya kegiatan MICE berskala nasional dan internasional yang menawarkan keunggulan baik konsep maupun arsitektur.

BNDCC menawarkan berbagai ruangan multifungsional dan ruang pertemuan bervariasi dari 20 sampai 5000 kursi, serta dirancang untuk mengakomodasi berbagai macam penataan ruangan. Produk dan layanan diciptakan khusus seperti layanan manajemen acara, pengaturan makanan minuman, peralatan audio visual, fasilitas telekomunikasi dan gudang, untuk memenuhi kebutuhan konsumen. Kelengkapan fasilitas yang dimiliki BNDCC selalu mendapat persaingan dari event venue lain. Hotel-hotel yang berada di area ITDC memiliki event venue, di samping 
adanya convention center lain yaitu Bali International Convention Centre (BICC), yang menjadi kompetitor dari BNDCC.

Bagaimana BNDCC menghadapi persaingan ditinjau dari sudut pandang pelaksanaan bauran pemasaran yang mencakup produk (product), harga (price), tempat (place), promosi (promotion), proses (process), orang (people) dan bukti fisik (phisycal evidence) atau dikenal dengan istilah bauran pemasaran 7P adalah merupakan tujuan dari penelitian ini.

\section{Tinjauan Pustaka}

Tinjauan pustaka pada penelitian ini membahas tentang bauran pemasaran mencakup 7P, yaitu: produk (product), harga (price), tempat (place), promosi (promotion), proses (process), orang (people) dan bukti fisik (phisycal evidence), event MICE dan venue MICE.

\subsection{Bauran Pemasaran}

Bauran pemasaran merupakan serangkaian elemen yang dirancang oleh perusahaan untuk menghasilkan tanggapan pasar (Samsul Arifin, 2019: 85), mencapai tujuan pemasaran (Freddy Rangkuti, 2009: 22) dan tingkat penjualan berdasarkan atas pasar sasaran (I Gusti Bagus Rai Utama, 2017: 26). Seberapa banyak elemen yang diperlukan tergantung pada kebutuhan, karena bauran pemasaran adalah alat pemasaran. Didin Fatihudin dan Anang Firmansyah (2019: 53) mengungkapkan bahwa bauran pemasaran jasa tidak cukup hanya empat, produk, harga, distribusi dan promosi, namun diperluas menjadi proses, orang dan bukti fisik, sehingga menjadi tujuh elemen.

Elemen-elemen bauran pemasaran di bidang jasa mencakup produk (product), harga (price), tempat (place), promosi (promotion), proses (process), orang (people) dan bukti fisik (phisycal evidence) atau dikenal dengan istilah bauran pemasaran 7P. 
a. Produk (product), harus dilihat sebagai suatu bundle of activities antara produk jasa inti dan pendukungnya, untuk menghasilkan total offering optimal, sehingga dapat memenuhi kebutuhan, keinginan dan harapan konsumen (Didin Fatihudin dan Anang Firmansyah, 2019: 53).

b. Harga (price), mengacu pada biaya produksi jasa dan ditentukan oleh permintaan pasar. Pencitraan produk yang kompetitif mempengaruhi keputusan penentuan harga (Francois Vellas dan Lionel Becherel, 2008: 142).

c. Tempat (place), mengacu pada tempat terjadinya kontak antara pemberi layanan dan yang mendapat layanan, berupa properti milik sendiri, manage properti lain atau sewa (Prasanna Kumar, 2010: 47).

d. Promosi (promotion), terdiri atas seluruh metode pengkomunikasian produk yang ditawarkan pada pasar yang ditargetkan. Peralatan promosi termasuk pemasangan iklan, media tv (Francois Vellas dan Lionel Becherel, 2008: 142).

e. Orang (people), mencakup orang-orang yang terlibat langsung maupun tidak langsung terhadap kegiatan pemasaran, sikap dan perilaku berpengaruh terhadap kualitas produk (Prasanna Kumar, 2010: 48).

f. Proses (process), adalah seluruh kegiatan kerja yang meliputi prosedur, tugas, jadwal, mekanisme, kegiatan dan runitas di mana suatu jasa disampaikan kepada pelanggan yang melibatkan kebijakan tentang keterlibatan pelanggan dan karyawan (Payne, 2009: 210)

g. Bukit Fisik (physical evidence), adalah lingkungan fisik perusahaan jasa di mana layanan diciptakan, penyedia jasa, pelanggan berinteraksi, ditambah unsur-unsur berwujud yang ada dan dipakai untuk berkomunikasi atau mendukung peran jasa (Payne, 2009: 164). 


\subsection{Event MICE}

Peraturan Menteri Pariwisata RI No.2 (2017) mengemukakan penyelenggaraan kegiatan pertemuan, perjalanan insentif, konvensi, dan pameran (meeting, incentive, convention, exhibition) yang selanjutnya disebut MICE adalah pemberian jasa bagi suatu pertemuan sekelompok orang, penyelenggaraan perjalanan bagi karyawan dan mitra usaha sebagai imbalan atas prestasinya, serta penyelenggaraan pameran dalam rangka penyebarluasan informasi dan promosi suatu barang dan jasa yang berskala nasional, regional, dan internasional. MICE sebagai wisata konvensi, dengan batasan: usaha jasa konvensi, perjalanan insentif dan pameran merupakan usaha dengan kegiatan memberi jasa pelayanan bagi suatu pertemuan sekelompok orang (negarawan, usahawan, cendikiawan) untuk membahas masalah-masalah yang berkaitan dengan kepentingan bersama (Andini, 2014:7).

\subsection{Venue MICE}

Tempat Penyelenggaraan Kegiatan (Venue) MICE yang selanjutnya disebut Venue MICE adalah tempat atau lokasi diselenggarakannya suatu kegiatan pertemuan, perjalanan insentif, konvensi dan pameran (Peraturan Menteri Pariwisata RI No.2, 2017). Apabila suatu kejadian bukan merupakan suatu kebetulan, tetapi direncanakan, maka tempat tersebut dinamakan event venue walaupun tempat tersebut digunakan satu kali (Philip Berners, 2019).

\section{Metode Penelitian}

Metode yang digunakan dalam penelitian ini adalah metode kualitatif deskriptif, dengan mengumpulkan dan merangkum elemenelemen bauran pemasaran untuk mendapatkan gambaran yang jelas. Adapun elemen-elemen bauran pemasaran dalam penelitian ini mencakup, 
produk, harga, tempat, promosi, proses, orang dan bukti fisik terhadap Bali Nusa Dua Convention Center yang berlokasi di Kawasan Terpadu ITDC NW/1 Nusa Dua, Bali.

Jenis data pada penelitian ini adalah kualitatif untuk menguraikan elemen bauran pemasaran. Data kualitatif berupa uraian informasi yang diperoleh dari informan, responden, seperti produk, harga, distribusi atau tempat, promosi, proses, orang dan bukti fisik. Sumber data primer dan sekunder menjadi acuan dalam proses penelitian. Data primer diperoleh secara langsung dari informan dan responden, yaitu asisten direktur, sales manager, perwakilan dari bagian human resources department dan karyawan banquet. Data sekunder diantaranya berupa artikel yang diperoleh dari publisitas media masa internet, guna melengkapi dan mendukung data primer yang diperoleh.

Pengumpulan data menggunakan beberapa instrumen, berupa dokumen, pedoman wawancara dan kamera. Instrumen dokumen diantaranya mencakup penelitian-penelitian terdahulu, buku, jurnal, artikel dan data perusahaan. Pedoman wawancara dalam penelitian ini adalah sejumlah pertanyaan tertulis, guna memperoleh data dari informan dan responden. Perangkat kamera diperlukan untuk mendokumentasikan situasi venue sebagai penunjang penyajian data.

\section{Hasil Dan Pembahasan}

Hasil dan pembahasan ini membahas tentang bauran pemasaran mencakup 7P, yaitu: produk (product), harga (price), tempat (place), promosi (promotion), orang (people), proses (process), dan bukti fisik (phisycal evidence).

\subsection{Produk (Product)}

Produk inti Bali Nusa Dua Convention Centre (BNDCC) adalah convention center, sedangkan produk pendukungnya adalah event services, 
VIP room, food and beverage, technical services, ample car spacesecurity-safety, cafe-lounge, bounded warehouse dan hotel yang secara keseluruhannya merupakan bundle of activities.

a. Produk inti BNDCC adalah convention center yang mencakup berbagai kapasitas berikut:

1) Theatre dari 48 sampai 4800 kursi

2) Class room dari 24 sampai 2400 kursi

3) U shape dari 12 sampai 1299 kursi

4) Round table dari 20 sampai 2400 kursi

5) Reception dari 48 sampai 4800 kursi

b. Produk penunjang BNDCC terdiri dari beberapa komponen berikut:

1) Events Services adalah team kerja profesional yang membantu dalam pengaturan agar event berjalan lancar dan sukses.

2) Food \& Beverage bisa menyediakan makanan prasmanan untuk 10 hingga 5000 peserta, tidak saja di BNDCC tetapi bisa di manapun dengan kualitas terbaik.

3) VIP Room yang dilengkapi dengan interior kerajinan tangan dan pengaturan spesial sesuai permintaan.

4) Technical Services mencakup berbagai fasilitas seperti layanan Wi-Fi lebih dari 300 titik jangkauan, perlengkapan IT, presentasi.

5) Ample Car Space, Security and Safety yang menampung 400 kendaraan dengan tingkat keamanan tinggi.

6) Café and Lounge Jimbaran Cafe dan Seminyak Lounge sebagai tempat untuk menikmati kuliner nusantara maupun internasional.

7) Bonded Warehouse yaitu tempat khusus yang dipersiapkan untuk menyimpan peralatan dan perlengkapan termasuk dari luar negeri.

8) Bali Nusa Dua Hotel \& Convention berada di area BNDCC sebagai tempat ideal bagi para delegasi atau tamu yang tidak mengikuti maupun yang mengikuti event untuk beristirahat. 


\subsection{Harga (Price)}

Penetapan harga produk BNDCC dalam hal ini fasilitas tempat kegiatan atau venue dilakukan berdasarkan atas beberapa pertimbangan, yaitu: segmen pasar, batasan penawaran, kenaikan berkisar $10 \%$.

a. Segmen pasar yang dimaksud adalah tipe konsumen yang akan menyewa venue. Misalnya, harga untuk pemerintah berbeda dengan yang ditawarkan kepada perguruan tinggi untuk wisuda.

b. Batasan penawaran mengacu pada tingkat harga yang ditawarkan sampai pada batas harga kesepakatan, dalam hal ini pihak BNDCC menyepakati margin 10\% dari seluruh biaya yang dikeluarkan untuk suatu kegiatan.

Adapun, contoh-contoh paket dan harga produk yang ditawarkan oleh BNDCC, adalah sebagai berikut:

a. Half Day Meeting Package adalah IDR 350.000 per orang, termasuk:

1) Penggunaan ruang pertemuan selama 4 jam

2) $1 x$ coffee break

3) 1x makan siang atau malam

4) Buku catatan dan pulpen

5) Permen dan air minum mineral

6) Peralatan suara dan 2 microphones

b. Full Day Meeting Package adalah IDR 400.000 per orang, termasuk:

1) Penggunaan ruang pertemuan selama 8 jam

2) $2 x$ coffee break

3) 1x makan siang atau malam

4) Buku catatan dan pulpen

5) Permen dan air minum mineral

6) Peralatan suara dan 2 microphones

c. Full Board Meeting Package adalah IDR 600.000 per orang, termasuk: 1) Penggunaan ruang pertemuan selama 10 jam 
2) $2 x$ coffee break

3) 1x makan siang dan malam

4) Buku catatan dan pulpen

5) Permen dan air minum mineral

6) Peralatan suara dan 2 microphones

\subsection{Tempat (Place)}

Convention center di BNDCC bisa memberikan layanan untuk total 12.000 kursi yang terbagi pada dua gedung utama yaitu gedung BNDCC 1, terletak di sebelah kiri pintu masuk dan BNDCC 2 di sebelah kanan pintu masuk. Gedung BNDCC mencakup ground floor, mezanine floor, dan 1st floor.

\section{a. BNDCC 1}

1) Ground floor mencakup ruang Nusa Dua, Taman Sari, Uluwatu dan Jimbaran.

a) Nusa Dua terdiri dari ruang Nusa Dua 1, 2, 3, 4, 5, hall, east lobby, south lobby, east dan south lobby.

b) Taman Sari terdiri dari ruang Taman Sari 1, 2 .

c) Uluwau terdiri dari ruang Uluwatu 1, 2, 3, 4, 5, 6, 7 dan lobby.

d) Jimbaran terdiri dari lobby 1,2 dan outdoor space bernama Taman Jepun.

2) Mezanine floor terdapat ruangan Kintamani 1, 2, 3, 4, 5, 6, 7, 8 dan lobby $1,2,3$.

3) First floor terdapat Singaraja dan outdoor space.

a) Singaraja room terdiri dari Singaraja 1, 2, hall, lobby 1, 2, 3

b) Outdoor space bernama Singaraja Terrace.

b. BNDCC 2

1) Ground floor terdiri dari ruangan Pecatu dan Mengwi

a) Pecatu terdiri dari Pecatu 1, 2, 3, 5, Hall 1, 2, Hall 3, 5, Pre- 
Function, Hall, Lobby.

b) Mengwi terdiri dari Mengwi 1, 2, 3, 5, 6, 7, 8, 1-2, 3-5, 6-7, 78, 6-7-8, VIP lounge.

2) Mezanine terdiri dari ruangan Legian 1, 2, 3, 5, 6, 7, 8, 9, 1-2, 3-5, 6-7, 8-9, lobby, balcony.

3) First floor terdiri dari ruangan Tanjung Benoa terdiri dari ruangan hall dan lobby.

\subsection{Promosi (Promotion)}

Komunikasi produk BNDCC dilakukan di dua tempat yaitu Bali Sales Office dan Jakarta Sales Office.

a. Bali Sales Office (BSO)

Nusa Dua Resort Block NW/1, Badung, Bali, Indonesia

Telp: +62-361-773000

Email: info@baliconventioncenter.com

b. Jakarta Sales Office (JSO)

The City Tower Lt. \&, J1. M.H. Thamrin Kav. 81 Jakarta 10310.

Telp: +62-21-31996026, +62-21-31996027, +62-21-31996127

Fax: + 62-21-31996126

Metode promosi produk BNDCC dilakukan melalui online maupun offline. Promosi online melalui website www.baliconvention center.com. Promosi offline dilakukan melalui kerjasama dengan berbagai perusahaan dan lembaga pemerintah. BSO bekerja sama dengan event organizer, biro perjalanan wisata, instansi pemerintah daerah dan kampus, khususnya yang berada di Bali. JSO bekerja sama dengan berbagai perusahaan besar di Jakarta dan lembaga pemerintah pusat. 


\subsection{Orang (People)}

Jumlah karyawan yang bekerja di BNDCC sebanyak 130 orang. Adapun tim pemasaran yang langsung berkaitan dengan MICE khususnya di BNDCC Bali adalah 3 orang dan karyawan banquet berjumlah 10 orang, dan dibantu oleh bagian human resource department (HRD) sebanyak 3 orang. Bagian HRD mempunyai tugas mencari pekerja honorer apabila ada event besar yang memerlukan tenaga kerja banyak. Oleh karenanya bagian HRD bekerja sama dengan berbagai sekolah dan kampus pariwisata yang ada di Bali.

Keterbatasan tim pemasaran mengakibatkan jangkauan kunjungan ke perusahaan-perusahaan yang ada di Bali khususnya jadi terbatas. Kondisi ini mengakibatkan kurangnya informasi yang dimiliki oleh perusahaan-perusahaan terhadap BNDCC, sehingga kegiatan-kegiatan pertemuan ditawarkan kepada kompetitor.

Persaingan di antara event venue menjadi kendala tersendiri. Berbagai event venue dibangun baik yang bertujuan khusus untuk tempat penyelenggaraan suatu event maupun yang bersifat multi fungsi. Mempelajari ketatnya persaingan, diperlukan tim pemasaran yang aktif menawarkan produk atau paket-paket meeting yang bisa berlaku mulai grup kecil sampai besar.

\subsection{Proses (Process)}

Proses kegiatan berawal dari permintaan bagian promosi atau penjualan yang diteruskan kepada divisi event management. Divisi event management akan mengolah permintaan sesuai standar prosedur yang berlaku di BNDCC, dalam suatu pertemuan internal. Hasil kesepakatan dalam pertemuan akan dikomunikasikan kepada bagian banquet event order, yang akan menyiapkan ruangan mana yang akan digunakan, jumlah kursi, peralatan dan perlengkapannya. Selanjutnya, bagian operation akan 
mengecek segala keperluan yang harus disiapkan tersebut. Pertemuan akan dilakukan lagi untuk memastikan persiapan telah selesai, sebelum hari event akan dilangsungkan.

\subsection{Bukti Fisik (Physical Evidence)}

Lingkungan fisik BNDCC berupa bangunan terintegrasi dengan 3 bangunan utama yaitu BNDCC 1, BNDCC 2 dan Bali Nusa Dua Hotel and Convention (BNDHC). BNDCC 1 dan BNDCC 2 sebagai tempat penyelenggaraan indoor event, sedangkan BNDHC merupakan sarana penunjang akomodasi.

Secara keseluruhan BNDCC menawarkan 44 ruangan multifungsional dan fleksibel dengan total kapasitas hingga 12.000 kursi. Gedung BNDCC 1 memiliki 2 hall, yaitu Nusa Dua berukuran 4,400 meter persegi dan Singaraja berukuran 1,734 meter persegi. Gedung BNDCC 2 memiliki 2 hall, yaitu Pecatu berukuran 1,770 meter persegi dan Tanjung Benoa berukuran 920 meter persegi. Terdapat 32 ruang pertemuan yang difungsikan untuk istirahat makan siang, makan malam, seminar, dan konferensi. Kegiatan pertemuan outdoor juga tersedia yang berukuran 1500 meter persegi, bernama Taman Jepun, terletak di antara gedung BNDCC 1 dan BNDCC 2, bisa menjadi pilihan tempat makan malam untuk 400 tamu. Singaraja Terrace berada di lantai 2 dari Singaraja Hall dengan suasana alami bisa menampung 600 orang untuk acara cocktail.

BNDHC berada di area BNDCC dan merupakan hotel bintang 5 menawarkan layanan akomodasi untuk 96 kamar dengan tipe deluxe, premiere, deluxe suite, premiere suite, executive suite dan presidential suite. Fasilitas lain yang dimiliki BNDHC adalah restaurant, spa dan fitness, kolam renang serta lobby lounge. 


\section{Simpulan Dan Saran}

\subsection{Simpulan}

Pelaksanaan bauran pemasaran MICE di BNDCC yang mencakup 7P sudah berlangsung dengan baik. Adapun unsur-unsur yang termasuk dalam 7P tersebut, adalah:

a. Produk (Product) inti Bali Nusa Dua Convention Centre (BNDCC) adalah convention center, sedangkan produk pendukungnya adalah event services, VIP room, food and beverage, technical services, ample car space-security-safety, cafe-lounge, bounded warehouse dan hotel yang secara keseluruhannya merupakan bundle of activities.

b. Harga (Price), penetapan harga produk BNDCC dalam hal ini fasilitas tempat kegiatan atau venue dilakukan berdasarkan atas beberapa pertimbangan, yaitu: segmen pasar, batasan penawaran, kenaikan berkisar $10 \%$ dari total komponen.

c. Tempat (Place), convention center di BNDCC bisa memberikan layanan untuk total 12.000 kursi yang terbagi pada dua gedung utama yaitu gedung BNDCC 1, terletak di sebelah kiri pintu masuk dan BNDCC 2 di sebelah kanan pintu masuk. Gedung BNDCC mencakup ground floor, mezanine floor, dan 1st floor.

d. Promosi (Promotion), komunikasi produk BNDCC dilakukan di dua tempat yaitu Bali Sales Office dan Jakarta Sales Office, melalui media on line dan kerjasama off line.

e. Orang (People), jumlah karyawan yang bekerja di BNDCC sebanyak 130 orang. Adapun tim pemasaran yang langsung berkaitan dengan MICE khususnya di BNDCC Bali adalah 3 orang dan karyawan banquet berjumlah 10 orang, dan dibantu oleh bagian human resource department (HRD) sebanyak 3 orang.

f. Proses (Process) kegiatan berawal dari permintaan bagian promosi atau penjualan yang diteruskan kepada divisi event management. 
Selanjutnya diproses oleh bagian banquet event order, dan operation.

g. Bukti Fisik (Physical Evidence), lingkungan fisik BNDCC berupa bangunan terintegrasi dengan 3 bangunan utama yaitu BNDCC 1, BNDCC 2 dan Bali Nusa Dua Hotel and Convention (BNDHC). BNDCC 1 dan BNDCC 2 sebagai tempat penyelenggaraan indoor event, sedangkan BNDHC merupakan sarana penunjang akomodasi.

\subsection{Saran}

Pelaksanaan bauran pemasaran MICE di BNDCC sudah berlangsung dengan baik. Namun, pada elemen bauran orang atau karyawan (people), terdapat keterbatasan tim pemasaran. Persaingan yang ketat di antara event venue mengharuskan jalinan kerjasama dengan berbagai perusahaan. Hal ini bisa dilakukan dengan maksimal apabila pihak BNDCC menambah karyawan bagian tim pemasaran, sehingga bisa menjangkau lebih banyak perusahaan untuk diajak kerjasama.

\section{Daftar Pustaka}

Andini, Nyoman Dini. 2014. Pengelolan Wisata Konvensi. Yogayakarta: Graha Ilmu.

Arifin, H. Samsul. 2019. Pemasaran Era Millenium. Yogyakarta:

Deepublish Publisher (Grup Penerbitan CV. Budi Utama).

Berner, Philips. 2019. The Practical Guide to Managing Event Venues. New York: Routledge.

Damanik, Darmawan dan FX Setiyo Wibowo. 2018. Implementasi Stratego 4P Dalam Meningkatkan Frekuensi Public Event Di Harris Hotel And Convention Bekasi (HHCB). Jurnal National Conference of Creative Industry: Sustainable Tourism Industry for Economic Development Universitas Bunda Mulia, Jakarta. ISSN No: 2622-7436. Fatihudin, Didin dan Anang Firmansyah. 2019. Pemasaran Jasa (Strategi, Mengukur Kepuasan dan Loyalitas Pelanggan). Yogyakarta: Deepublish Publisher (Grup Penerbitan CV. Budi Utama).

Kumar, Prasanna. 2010. Marketing of Hospitality and Tourism Serices.

New Delhi: Tata McGraw Hill Education Private Limited.

Payne. 2009. The Essence Of Service Marketing, Pemasaran Jasa. Edisi

II. Diterjemahkan: Fandy Tjiptono. Yogakarta: Penerbit Andi. 
Peraturan Menteri Pariwisata Republik Indonesia Nomor 2 Tahun 2017 tentang Pedoman Tempat Penyelenggaraan Kegiatan (Venue) Pertemuan, Perjalanan Insentif, Konvensi dan Pameran.

Rangkuti, Freddy. 2009. Strategi Promosi yang Kreatif dan Analisis Kasus Integrated Marketing Communication. Jakarta: Gramedia Pustaka Utama.

Utama, I Gusti Bagus Rai. 2017. Pemasaran Pariwisata. Yogyakarta: Penerbit Andi.

Vellas, Francois dan Lionel Becherel. 2008. Pemasaran Pariwisata Internasional. Pengantar: I Gede Ardika. Penerjemah: Indriati. Jakarta: Yayasan Obor Indonesia.

Yunita, Linda Desma dan Tri Handayani. 2018. Strategi Bauran Promosi Penyelenggaraan Event (Studi Kasus Perencanaan dan Penyelenggaraan Event Pasar Murah). Jurnal Riset Bisnis dan Investasi Vol. 4, No. 1, April 201815 ISSN 2460-8211. 